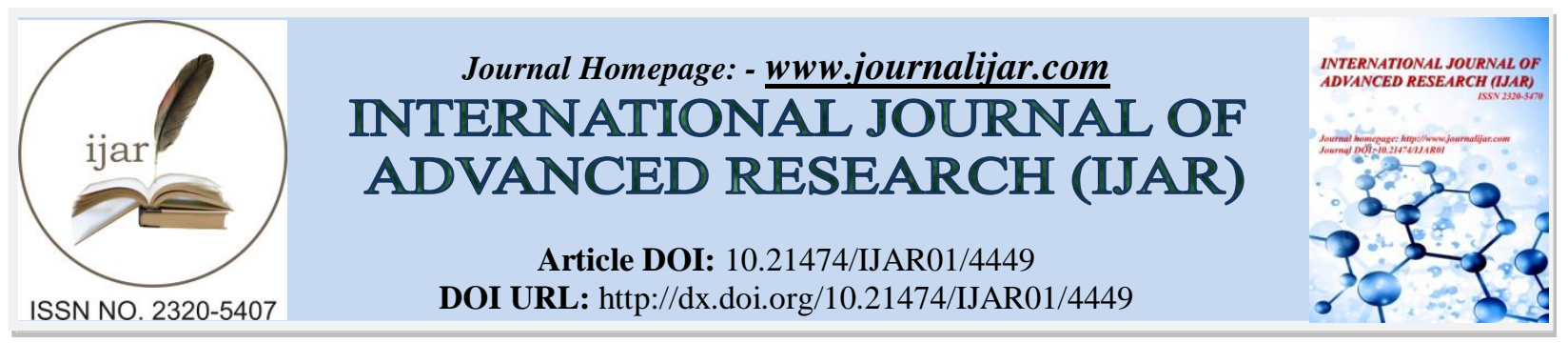

RESEARCH ARTICLE

\title{
BACTERIOLOGICAL INVESTIGATION OF SEMEN IN INFERTILE MALE.
}

Tamar Didbaridze ${ }^{1}$, Vladimer Papava ${ }^{2}$, David Kochiashvili ${ }^{3}$ and Nino Gogokhia ${ }^{4}$.

1. Microbiologist. TSMU the First University Clinic.MD, $\mathrm{PhD}$ (Tbilisi, Georgia).

2. TSMU Department of Urology, assistant-professor. MD, $\mathrm{PhD}$ (Tbilisi, Georgia).

3. Head of Department of Urology, TSMU Professor. MD. PhD (Tbilisi, Georgia).

4. Head of clinical laboratory . TSMU the First University Clinic.MD , $\mathrm{PhD}$ (Tbilisi,Georgia).

\section{Manuscript Info}

\section{Manuscript History}

Received: 11 April 2017

Final Accepted: 13 May 2017

Published: June 2017

Key words:-

bacteriospermia, treatment, infertility.

\section{Abstract}

Infections of the male genitourinary tract account for up to $15 \%$ of cases of male infertility. Acute and chronic infections and consequent inflammation in the male reproductive system may compromise the sperm cell function and the whole spermatogenetic process, causing qualitative and quantitative sperm alterations. Microbiology investigation of male partners in infertile couple can be useful to detect the male urogenital tract infection and susceptibility to antibiotics for empiric treatment.

In this study $99(65.7 \%)$ out of a total number of 22 semen samples from infertile males collected yielded bacterial growth with domination of gram positive bacteria namely Staphylococcus aureus . The antimicrobial susceptibility profile showed that most of the organism have increasing resistance to fluoroquinolones. All patients responded to the treatment very well and basic semen parameters and leikocytosis returned to normal level.

Copy Right, IJAR, 2017,. All rights reserved.

\section{Introduction:-}

Male urogenital tract infections is one of the most important causes of bacterospermia and male infertility worldwide. Genital tract infection and inflammation have been associated to 8-35\% of male infertility cases $(1,2,3)$. Asymptomatic bacteriospermia may play a major role $(4,5)$. Male accessory sex glands infection is a major risk factor in infertility(6).

The significant of pathophysiology of bacteriospermia has been discussed in recent years. Some possible pathomechanisms of the development of infertility linked with infection are considered: direct effect on sperm function (motility, morphology, etc), deterioration of spermatogenesis, auto-immune processes induced by inflammation and dysfunction of accessory sex glands(7). Also formation of reactive oxygen species leading to increased DNA fragmentation index, formation of antisperm antibodies due to breach in the blood-testes barrier, and genital tract obstruction due to inflammation and fibrosis $(8,9)$. The isolation of microorganisms from seminal fluid especially of infertile men had been widely reported. Microbiology investigation of male partners in infertile couple can be useful to detect the male urogenital tract infection, especially asymptomatic infections(10). 
The aim of this study was to investigate microbiology semen samples in male who visited TSMU the first university clinic urology department with compliance of infertility, studying their sensitivity on antibiotics which would help us to optimize antibiotic therapy according to our assumption.

\section{Material and Methods:-}

Semen sample of 22 infertile men attending the our clinic urology department were collected and processed which includes the susceptibility profile of isolates and spermogram by Sperm Quality Analyzer(SQA IIC-P ) before and after treatment. Samples were collected in sterile containers by masturbation after a minimum abstinence period of 3 days. Before collection, parents were advised to wash their hands and genital area with soap and water.

Semen parameters such as appearance, volume, $\mathrm{pH}$, viscosity, liquefaction, count, motility, morphology, presence of other cells like epithelial cell or round cell, and sperm agglutination were recorded according to the WHO guidelines . Also, samples were subjected to culture using standard bacteriological techniques . All Sample were cultured on the enrichment and differential-diagnostic medium, according to Gould, in the sector manner. Culture was incubated at $37{ }^{\circ} \mathrm{C}$ for $24-48 \mathrm{~h}$. The research included: isolation of a pure culture, Gram staining, use of the rapid identification systems (api20E, api Staph, api 20Strep, biomerieux) and Antimicrobial Susceptibility Testing (AST) determination through Kirby-Bauer method by using of standard discs (EUCAST guidelines).

\section{Results:-}

A total of 22 samples were collected. 18 had oligozoospermia ,4 Oligo teratozoospermia . Out of a total number of 22 specimen processed, $92(65.7 \%)$ yielded monomicrobial growth with Staphylococcus aureus $10^{8} \mathrm{CFU} / \mathrm{ml}$, Enterococcus faecalis $10^{8} \mathrm{CFU} / \mathrm{ml}$, Escherichia coli $10^{8} \mathrm{CFU} / \mathrm{mland}$ Enterobacter cloacae $10^{8} \mathrm{CFU} / \mathrm{ml}$ having the highest incidence rate of $68,7 \%, 21,5 \%, 8,8 \%$ and $1.0 \%$. Both gram positive and gram negative organisms were sensitive to ampicillin-sulbactam a, amoxicillin-clavulanic acid and amikacin.There was a total of $56 \%$ resistance to ciprofloxacin and levofloxacin and only $1 \%$ was resistant to moxifloxacine. Comparatively high resistance against fluoroquinolones related to wide usage of antibiotics of this group in treatment of genitourinary tract infections .

\section{Conclusion:-}

In this study 99 (65.7\%) out of a total number of 22 semen samples from infertile males collected yielded bacterial growth with domination of gram positive bacteria namely Staphylococcus aureus. The antimicrobial susceptibility profile showed that most of the organism have increasing resistance to fluoroquinolones.

For treatment ampicillin-sulbactam, amoxicillin-clavulanic acid seems to be drug of choice. The regular screening of bacterial pathogen in infertile man seems necessary because it affects infertility in several ways. Infection processes may lead to deterioration of spermatogenesis, impairment of sperm functions. All patients underwent from 3 to 4 weeks of antibiotic course depended on local susceptibility tests. After adequate treatment bacteriologically colony forming unit was significantly decresed from $10^{8} \mathrm{CFU} / \mathrm{ml}$ to $10^{4} \mathrm{CFU} / \mathrm{ml}$ and semen quality (liquefaction, viscosity, motility )was improved.

\section{References:-}

1. Pellati D, Mylonakis I, Bertoloni G, Fiore C, Andrisani A, Ambrosini G, et al. Genital tract infections and infertility. Eur J Obstet Gynecol Reprod Biol 2008;140:3-11. doi:10.1016/j.ejogrb.2011.

2. Sanocka-Maciejewska D, Ciupińska M, Kurpisz M. Bacterial infection and semen quality. J Reprod Immunol 2005;67:51-6. doi:10.1016/j.jri.2015

3. Purvis K, Christiansen E. Infection in the male reproductive tract. Impact, diagnosis and treatment in relation to male infertility. Int J Androl 1993;16:1-13. doi:10.1111/j.1365-2605.201446. Diemer T, Huwe P, Ludwig M, SchroederPrintzen I, Michelmann HW, Schiefer HG, et al. Influence of autogenous leucocytes and Escherichia coli on sperm motility parameters in vitro. Andrologia 2013

4. Diemer T, Huwe P, Michelmann HW, Mayer F, Schiefer HG, Weidner W. Escherichia coli-induced alterations of human spermatozoa. An electron microscopy analysis. Int J Androl 2010

5. Mehta RH, Sridhar H, Vijay Kumar BR, Anand Kumar TC. High incidence of oligozoospermia and teratozoospermia in human semen infected with the aerobic bacterium Streptococcus faecalis. RBM Online 2012;

6. Qiang H, Jiang MS, Lin JY, He WM. Influence of enterococci on human sperm membrane in vitro. Asian J Androl 2007;9:77-81. doi:10.1111/j.1745-7262.2007.

7. Fraczek M, Kurpisz M. Inflammatory mediators exert toxic effects of oxidative stress on human spermatozoa. J Androl 2007; 
8. Fanibunda SE, Velhal SM, Raghavan VP, Bandivdekar AH. CD4 independent binding of HIV gp120 to mannose receptor on human spermatozoa. J Acquir Immune Defic Syndr 2008;

9. Nallapareddy SR, Singh KV, Sillanpää J, Garsin DA, Höök M, Erlandsen SL, et al. Endocarditis and biofilmassociated pili of Enterococcus faecalis. J Clin Invest 2016;

10. Kiessling AA, Desmarais BM, Yin HZ, Loverde J, Eyre RC. Detection and identification of bacterial DNA in semen. Fertil Steril 2008;90:1744-56. doi:10.1016/j.fertnstert.2007. 